\title{
IMPACT OF TECHNOLOGICAL AND NON-TECHNOLOGICAL INNOVATION ON FIRM PERFORMANCE: EMPIRICAL STUDY AT TURK TELEKOM GROUP ANTALYA OFFICE
}

\author{
*Khamroz ABDUKHOSHIMOV \\ *Eren DURMUŞ-ÖZDEMIR \\ "Akdeniz University
}

\begin{abstract}
The aim of this study is to explore the impacts of technological (product innovation and process innovation) and non-technological innovation (organizational and marketing innovations) on firm performance. The research questions were pursued through questionnaires with top-level managers of a firm operating in Turkish telecommunication industry, Turk Telekom Group Antalya Office. Analysis results demonstrated that technological innovation (product and process innovation) and marketing innovation has significant and positive impact on firm performance, but no evidence was found for a significant and positive relationship between organizational innovation and firm performance in Turk Telekom Group Antalya Office.
\end{abstract}

Keywords: technological innovation; non-technological innovation; firm performance; Turk Telekom Group

\section{INTRODUCTION}

This paper aims to investigate the impacts of technological and non-technological innovation on firm performance in a company operating in Turkish telecommunication industry. Innovation literature claims that innovation has become a requisite objective for all firms (Darroch, 2005; Jiao, Cui, Yunxia, \& Chen, 2014). According to Koc \& Ceylan (2007), innovation is the ability of an organization to successfully adopt or implement new ideas, processes or products, as it is key to gain a competitive advantage. Despite the plurality of definitions for innovation in the literature, there is no global consensus on the exact definition of the term. Some scholars described innovation as an idea, a product or process, or a system that is perceived to be something new to an individual (Vakola \& Rezgui, 2000), as an initiation, adoption, and implementation of new ideas or activities (Chen \& Tsou, 2007), as an addition to new knowledge (Lundvall \& Nielsen, 2007). The arguments on this subject are still under review because of the researchers' inconsistent classifications of innovation. For example, in the study of Damanpour (1991), it was proposed that innovation had sought out new ideas in its administrative domains, which was consistent with the classifications of the previous study conducted by Kırım (2007) and Huiban \& Bouhsina (1998), all of whom pointed to the importance of business innovations. However, another study by Dewar \& Dutton (1986), demonstrated that innovation can be classified into two types as radical and incremental. In other studies, innovation was distinguished two types, namely, product and process innovations. As both innovation types associated with the development of new or considerably improved existing technologies, these innovations are often labeled as technological innovations (OECD \& Eurostat, 1997; Schmidt \& Rammer, 2007). However, the earlier concept drew strong criticism for not fully capturing service innovations (Hipp, Tether, \& Miles, 2000; Hipp \& Grupp, 2005) as well as ignoring innovative activities of firms, e.g. adopting new and/or re-organizing existing business routines, external relations and marketing strategies (Boer \& During, 2001; Baranano, 2003).

There is another group of studies, which indicated the innovation as combining elements of both technological and non-technological innovations (Griffin \& Hauser, 1996; Tidd, Bessant, \& Pavitt, 2001; Cozzarin \& Percival, 2006; Elçi, 2007; Schmidt \& Rammer, 2007; Jaskyte, 2011). According to the findings of these authors, technological innovations covers process and product types, while nontechnological innovations covers the marketing and organizational types. Also, these studies highlighted the importance of integrating technological innovations and non-technological innovation for the successful transfer of new ideas and new business opportunities into market success. Griffin \& Hauser 
(1996) stated that it was crucial to linking research and development, technological innovation and marketing strategies to gain competitive advantage. Schmidt \& Rammer (2007) proposed that in order to capture a broader picture of innovative efforts of firms across all economic units, the innovation concept should be extended to non-technological innovation. The number of studies based on the classification of four types of innovation described in the Oslo Manual (OECD \& Eurostat, 2005) as product, process, organizational and marketing innovations. In the third edition of the Oslo Manual, these classifications contained technological and non-technological innovations in detail. Therefore, the authors of this article focused on these classifications.

Despite the fact that innovation is found to be vital for firm performance, few studies focused on the relationship between firm performance and specific types of innovations: technological and nontechnological innovation. This study aimed to fill the gap in the literature by testing this relationship in a firm operating in Turkish telecommunication industry. Therefore, the current study attempts to analyze the impacts of technological and non-technological innovation on firm performance.

The paper is organized as follows: The first section summarizes the literature regarding technological innovation and firm performance. Next section deals with methodology and findings of the field study. Finally, the findings are discussed, limitations are presented and some recommendations are proposed for further research.

\section{LITERATURE REVIEW AND HYPOTHESIS Technological and non-technological innovation}

In a competitive environment, effective innovation policy of a firm increases its chances of gaining an advantage over rival firms in the market. Schumpeter first described the term 'innovation' in 1934 as 'the driving force for development'. The implication of his definition is that innovation is likely to be a dynamic rather than a static form of creativity. Following work increasingly made the argument that innovation is important as a crucial source of performance which is, in turn, claimed to be one of the key factors for firm success and survival (Mumford \& Licuanan, 2004; Johannessen, 2008; Bartel \& Garud, 2009; Standing \& Kiniti, 2011). For example, Vakola and Rezgui (2000) define innovation as an idea, a product or process, or a system that is perceived to be new to an individual. Thus, innovation can occur in the domains of product, process, organizational and marketing strategies. In the longitudinal study by Artz et al. (2010), the impact of patents acquired and product innovations on firm performance in different industries of the U.S. and Canada were explored. They found that product innovations had a significant impact on firm performance. Therrien, Doloreux \& Chamberlin (2011) define that innovation is a complex process related to changes in production functions and processes whereby firms seek to acquire and build upon their distinctive technological competence, understood as the set of resources a firm possesses and the way in which these are transformed by innovative capabilities.

Despite the plurality of definitions for innovation is presented in the literature, the arguments on this subject are still under review because of the researchers' inconsistent classifications of innovation. While some studies suggested managerial and organizational innovations (Damanpour, 1991; Huiban \& Bouhsina, 1998; Kırım, 2007), others emphasized marketing innovations (Higgins, 1995; Naidoo, 2010). According to the first and second editions of Oslo Manual, innovations were often associated with the development or application of new technologies. New products contain new technical features, which offer new functionalities, enhance product quality as well as allow for new areas of application. Meanwhile, process innovations rest on the use of new technologies to increase the efficiency or quality of production and service (Schmidt \& Rammer, 2007). Later, this view was criticized because of lack of attention to innovations in service; ignoring business routines, internal organization, and external relations and underestimating the importance of marketing strategies (Hipp, Tether, \& Miles, 2000; Boer \& During, 2001; Baranano, 2003; Hipp \& Grupp, 2005).

In the third edition of the Oslo Manual, the definition was extended to encompass non-technological characteristics of product and process innovation, such as organizational, logistic and marketing changes (OECD \& Eurostat, 2005). After these classifications, many studies described the innovation as combining elements of both technological and non-technological innovations (Griffin \& Hauser, 1996; Tidd, Bessant, \& Pavitt, 2001; Cozzarin \& Percival, 2006; Elçi, 2007; Schmidt \& Rammer, 2007; Jaskyte, 2011). Technological innovation involves product and process innovations while non-technological innovation involves marketing and organizational innovations. Phillips (1997) separated technological 
and non-technological innovation and included new marketing strategies and changes to management techniques or organizational structures. Schmidt \& Rammer (2007) analyzed the impacts of nontechnological innovations contrasting those patterns with the determinants of technological innovations. They found that the share of firms introducing only technological innovations (13\%) is lower than the share of firms introducing only non-technological innovations (24\%). Ali-Yrkkö \& Martikainen (2008) analyzed the impact of technological and non-technological innovations using data from an ad-hoc survey conducted in 2008. Damanpour (2013) showed the (small) managerial literature on the synchronous versus sequential occurrence within a firm of technological and non-technological innovations. $\mathrm{He}$ concluded that the arguments are strong for simultaneity, but that rigorous empirical work is needed to know how firms really behave. The current study is based on the classification of four types of technological and non-technological innovation described in the Oslo Manual (OECD \& Eurostat, 2005) as product, process, organizational and marketing innovations.

Product innovation involves entirely new goods and services, as well as significant improvements to existing products. Process innovation is the implementation of new or significantly improved methods of production or delivery. These include significant changes in techniques, equipment, and/or software. Process innovation represents significant changes in the production process and delivery methods. Organizational innovation refers to the implementation of a new organizational method in the firm's business practices, firm organization or external relations. Such organizational innovations can be intended to improve a firm's performance by reducing administrative costs or transaction costs, increasing workplace satisfaction, gaining access to non-tradable assets or reducing costs of supplies. Marketing innovation is the implementation of a new marketing method, involving significant changes in product design or packaging, product placement, product advertisement or pricing.

\section{Turkish telecommunication industry}

The authors of this article focused on telecommunication industry in Turkey which is one of the most innovative industries in the country, and has achieved an assertive position with its mobile phone subscribers; asymmetric digital subscriber line customers and quality in the field telecommunication industry (www.invest.gov.tr, 2015). This industry also contributes to the improvement of the competitive power of the country by investing and innovating continuously, creating technical jobs, and spreading the technical culture to the other relevant industries and to the society in general. Finally, the reason behind the industry preference is due to the importance of the added value and industrialization of the country.

The field study of the present study was carried out the first and the largest integrated telecommunications company, Turk Telekom Group-Antalya Regional Office (further mentioned as TTG Antalya Office in the text) in Turkey. Turk Telekom Group, with 175 years of history, is one of the leading firms in the telecommunication industry that has been experiencing a rapid and dynamic growth in Turkey. As the "Quadruple Player of Turkey," Turk Telekom Group Companies offer a complete range of mobile, fixed voice, broadband and TV services. This company has a wide service network and product range in the fields of individual and corporate services. As of March 11, 2016, The company reported that it posted more than TL 2 billion (approximately \$1 billion) net income in 2014. As of December 31, 2015, The Group has 12.9 million fixed access lines, 8 million broadband and 17.3 million mobile subscribers. This firm provides services in all 81 cities of Turkey with more than 34,000 employees with the vision of introducing new technologies to Turkey and accelerating Turkey's transformation into an information society. Also, it offers a wide range of services, including home telephone, broadband connection, mobile services, TV and as well as innovative convergence technologies.

\section{Development of hypothesis}

In the literature, some studies are existed that have examined the relationship between innovation and performance. By the end of the 1990s, references to innovation in contemporary business publications were commonplace for firm performance (Wiig, 1997; Nelson \& McCann, 2010). While some studies revealed that process innovation improved performance (Olson \& Schwab, 2000; Knott, 2001; Yang, 2010), others suggested that product, marketing or organization innovations was linked to different aspects of performance (Atuahene-Gima, 1996; Subramanian \& Nilakanta, 1996; Han, Kim, \& Srivastava, 1998; Li \& Atuagene-Gima, 2001). For example, Johne \& Davies (2000) argued that marketing innovations increased sales by increasing product consumption and bringing additional profit to the firm. Lin \& Chen (2007) associated innovations with increased sales, despite finding a weak link. 
In addition, they suggested that non-technological innovations (organizational and marketing) rather than technological innovations (product and process) appeared to be the most important factor for total sales. Naidoo (2010) found a relationship between market orientation, marketing innovation, competitive advantage and firm performance. According to Naidoo (2010), market-oriented firms are actively involved in marketing innovation, which positively affects firm's competitive advantage. JiménezJiménez \& Sanz-Valle's (2011) found a positive relationship among organizational learning, innovation and firm performance in their study. A similar result was supported by the study of Calantone, Cavusgil, $\&$ Zhao (2002). Their study revealed that firm innovativeness is positively related to firm performance in the U.S. manufacturing and service industries.

There is still a small body of research in the literature addressing the issue of combining elements of both technological and non-technological innovation that simultaneously lead to better performance (Schmidt \& Rammer, 2007; Gunday, Ulusoy, Kilic, \& Alpkan, 2011; Atalay, Anafarta, \& Sarvan, 2013; Camison \& Vellar-Lopez, 2014). Gunday et al. (2011) found a positive relationship between non-technological innovations and firm performance, through an empirical study covering Turkish manufacturing firms in different industries. Atalay, et al. (2013) studied the relationship between innovation and firm performance in Turkish automotive supplier industry. They found that technological innovation had a significant and positive impact on firm performance. Özen (2014) conducted a survey as an application on the technological and non-technological innovations of four basic elements; product (service), process, organization and marketing, that affect the performance of the carpet-producing firms in Gaziantep province. According to study results, it was observed that the factors such as increment of the number of product variety, improvement the product quality, reduction of the product cost, which are thought they compose the innovation, have a positive effect on the performance of the firms. Uyar \& Kilicaslan (2015) studied how often customers of Turkish service industry pay attention to firms' innovativeness. The results of their study suggested that all segments of the society pay close attention to innovation, that they lean towards innovation when buying products, and that innovative businesses always tend to be preferred. The authors also suggested that firms with good innovation strategies and marketing activities are more likely to gain valuable competitive advantage, thus highlighting the importance of both technological and non-technological innovation on firm performance. Camison \& Villar-Lopez (2014) studied the relationship between organizational innovation and technological innovation and analyzed their effect on firm performance. According to the findings of their study, organizational innovation favors the development of technological innovations and altogether both innovation types lead to the superior firm performance.

As explained above, the arguments on this subject are still under review because of only a few studies tried to find the impacts of technological and non-technological innovations on firm performance in the service sector such like telecommunication industry. With a view to contributing to the gap in the literature, the aim of the present paper is to investigate the impacts of technological and non-technological innovation on firm performance in a company operating in Turkish telecommunication industry, namely in TTG Antalya Office. Basing on the above-mentioned theoretical and empirical findings in the literature, the following hypotheses are proposed:

H1: Technological innovation positively affects firm performance.

Hla: Product innovation positively affects firm performance.

HIb: Process innovation positively affects firm performance.

H2: Non-technological innovation positively affects firm performance.

H2a: Organizational innovation positively affects firm performance.

$\mathrm{H} 2 \mathrm{~b}$ : Marketing innovation positively affects firm performance

\section{METHODOLOGY \\ Data collection method and sample}

This present study is focused on TTG Antalya Office, which has achieved an assertive position with its fixed line customers, broadband customers (wholesale), and mobile line customers, gained a share in the national market in the telecommunication industry in Turkey. Although TTG provides its services in all 81 cities of Turkey, Antalya has been increasingly attracting attention in recent years. For example, TTG Antalya Office has enjoyed a high total volume trade rate in recent years and provided considerable contributions to the economy of Turkey. Hence, it has more than 1.500 employees. Turk Telekom has the 
vision of being the leading provider of communication technologies in Turkey and the surrounding regions, especially the region of Antalya. In line with this vision, TTG developed "Turk Telekom Portal" project in late 2014 which aims to develop effective innovation management within an organization, to offer the most innovative solutions to customers, and to improve firm performance. Antalya region was chosen as the first pilot region within the scope of this project in Turkey. The project covered all of TTG Antalya Office's departments and focused on the installation and operationalization of new infrastructure data and IT devices and new Turk Telekom-TTNet-Avea system definitions. It also consolidated the company's intranet portals. In accordance with the objectives of the study, the sample for the study only consisted of those departments of the firm engaged in infrastructure projects and actively using the innovational system for daily operations. Thus, in this present study, it seemed worthwhile to investigate the conceptual relations of TTG Antalya Office.

Data of the study collected through revised version of questionnaires with top-level managers of the TTG Antalya Office. A preliminary pilot study was conducted among the top-level managers of the telecommunications industry in Turkey, to evaluate an effective sample size and the reliability of the questionnaires intended for use in the main study. The data was gathered over a two-month period (October-December 2015). For the survey, the web-based questionnaire link was emailed to the company. With follow-up telephone calls and emails, 62 (out of 150) completed questionnaires were collected. A total of 59 questionnaires were usable, producing a response rate of $39.33 \%$.

\section{Data collection tool}

For the purpose of testing the above-stated hypotheses, a questionnaire form was designed consisting of an Innovation scale adapted from Lin et al. (2010) comprising 19 items and a Firm Performance scale adapted from Venkatraman (1989) comprising 10 items. In this study, subjective measures of performance were evaluated due to the difficulty of gathering hard financial data from the sample company (Venkatraman, 1989). These tools were based on the previous studies, pilot study and publications about telecommunication industry. Including Innovation and Firm Performance scales, which are shown in Table 1, the survey consists of 29 items.

Table 1. Measures

\begin{tabular}{llll}
\hline Measure & Developers & Implemented Scale (items) & Original Scale (items) \\
\hline Innovation & Lin et al. (2010) & 19 & 25 \\
Firm Performance & Venkatraman (1989) & 10 & 8 \\
\hline
\end{tabular}

\section{Factor analysis and reliabilities}

Table 2 shows four-factor loadings of the independent variables in the shape of 'Marketing Innovation', 'Organizational Innovation', 'Product Innovation' and 'Process Innovation' which together explained $62.980 \%$ of total variance. The Kaiser-Meyer-Olkin Measure of Sampling Adequacy (KMO) value was 0.679 , which is acceptable and significant. The dependent variable in the shape of 'Firm Performance' in Table 3 explained $58.021 \%$ of the total variance, which is close to $60 \%$ and the respective KMO value for this factor was 0.885 , which is acceptable and significant. Consequently, all the mentioned results of factor analysis are in acceptable range (Lewis-Beck, 1994).

\section{Table 2. The Results Of Innovation Factor And Reliability Analysis}

\begin{tabular}{|c|c|c|c|c|c|}
\hline \multirow{2}{*}{$\begin{array}{l}\text { Innovation Factors } \\
\text { Items }\end{array}$} & \multicolumn{2}{|c|}{$\begin{array}{l}\text { Non-technological } \\
\text { Innovation }\end{array}$} & \multicolumn{2}{|c|}{ Technological Innovation } & \multirow[b]{2}{*}{ TOTAL } \\
\hline & $\begin{array}{l}\text { Marketing } \\
\text { Innovation }\end{array}$ & $\begin{array}{l}\text { Organ-1 } \\
\text { Innovation }\end{array}$ & $\begin{array}{l}\text { Product } \\
\text { Innovation }\end{array}$ & $\begin{array}{l}\text { Process } \\
\text { Innovation }\end{array}$ & \\
\hline $\begin{array}{l}\text { Our company continually enlarges potential } \\
\text { demand markets }\end{array}$ & 0.901 & & & & \\
\hline $\begin{array}{l}\text { Our company adopts innovative and follow-up } \\
\text { systems for enhancing customer satisfaction }\end{array}$ & 0.766 & & & & \\
\hline With NPD, our company enlarges new markets & 0.643 & & & & \\
\hline $\begin{array}{l}\text { Our company leads innovative pricing methods } \\
\text { in markets }\end{array}$ & 0.599 & & & & \\
\hline
\end{tabular}




\begin{tabular}{|c|c|c|c|c|c|}
\hline $\begin{array}{l}\text { Our company adopts innovative administration } \\
\text { aiming at NPD }\end{array}$ & & 0.787 & & & \\
\hline $\begin{array}{l}\text { Our company engages in organizational } \\
\text { reconstruction for pursuing operational } \\
\text { efficiency }\end{array}$ & & 0.765 & & & \\
\hline Our company adopts innovative work designs & & 0.601 & & & \\
\hline $\begin{array}{l}\text { Our company extends numbers of product and } \\
\text { service lines }\end{array}$ & & & 0.742 & & \\
\hline $\begin{array}{l}\text { Process control technologies used in } \\
\text { infrastructure projects allows serving various } \\
\text { demands }\end{array}$ & & & 0.708 & & \\
\hline $\begin{array}{l}\text { Our company leads innovative promoting } \\
\text { methods to markets }\end{array}$ & & & 0.619 & & \\
\hline $\begin{array}{l}\text { Our company launches new products and } \\
\text { services }\end{array}$ & & & 0.563 & & \\
\hline $\begin{array}{l}\text { Our company engages in new product } \\
\text { development (NPD) to obtain patents }\end{array}$ & & & & 0.907 & \\
\hline $\begin{array}{l}\text { Our company launches customized product and } \\
\text { services according to market demands }\end{array}$ & & & & 0.633 & \\
\hline $\begin{array}{l}\text { Our company adopts advanced real-time } \\
\text { process control technology }\end{array}$ & & & & 0.614 & \\
\hline Factor Extraction (\%) & 31.626 & 11.345 & 10.620 & 9.389 & 62.980 \\
\hline Reliability Analysis (Cronbach's Alpha) & 0.760 & 0.704 & 0.670 & 0.665 & $0.827^{*}$ \\
\hline
\end{tabular}

As shown in Table 2 some items used in the questionnaire were excluded from the study owing to low factor loading. Five items that initially appeared in Innovation scale were excluded from factor analysis one at a time until acceptable and significant factor loadings were achieved. The value of Cronbach's alpha for all factors is compatible with the recommended threshold level of 0.60 (Hair, Anderson, Tatham, \& Black, 1998).

Table 3. The Results Of Performance Factor And Reliability Analysis

\begin{tabular}{|c|c|c|c|}
\hline \multicolumn{4}{|l|}{ Firm Performance } \\
\hline Items & $\begin{array}{c}\text { Factor } \\
\text { loadings }\end{array}$ & $\begin{array}{l}\text { Factor Extraction } \\
(\%)\end{array}$ & $\begin{array}{l}\text { Reliability Analysis } \\
\text { (Cronbach's Alpha) }\end{array}$ \\
\hline Satisfaction with sales revenue & 0.872 & 58.021 & 0.914 \\
\hline To sum up, our firm performance level is high & 0.825 & & \\
\hline Customer satisfaction & 0.800 & & \\
\hline Satisfaction with customer relations management & 0.791 & & \\
\hline Profit margin & 0.791 & & \\
\hline Satisfaction with extensive customer service & 0.744 & & \\
\hline Satisfaction with promoting methods of services & 0.730 & & \\
\hline Price level & 0.694 & & \\
\hline Sales growth position relative to competition & 0.680 & & \\
\hline \multirow[t]{2}{*}{ Satisfaction with return on corporate investment } & 0.662 & & \\
\hline & TOTAL & 58.021 & \\
\hline \multicolumn{2}{|c|}{ Kaizer Meyer Olkin Measure of Sampling Adequacy } & 0.885 & \\
\hline \multicolumn{2}{|c|}{ Bartlett Test of Sphericity Chi-Square } & 381.084 & \\
\hline \multicolumn{2}{|r|}{ df } & 45 & \\
\hline \multicolumn{2}{|r|}{ Sig. } & 0.000 & \\
\hline
\end{tabular}




\section{RESULTS}

\section{Correlations}

Correlation tests between pair wise factors are shown in Table 4, which contains the inter-correlations among the factors used in the study. The correlation matrix shows that all but the organizational dimension of innovation are strongly correlated with firm performance. Among the technological innovation dimensions both product $(\beta=0.397, \mathrm{p}<0.01)$ and process innovation $(\beta=0.378, \mathrm{p}<0.01)$ have a strong positive effect on firm performance. On the other hand, non-technological innovation dimensions, at least in this study partially affect firm performance. Marketing innovation $(\beta=0.489, p<0.01)$ has a strong direct effect on firm performance, whereas organizational innovation $(\beta=0.172)$ does not influence firm performance. The authors take a closer look at the misleading and real values in the regression test.

Table 4. Correlations

\begin{tabular}{|c|c|c|c|c|c|c|c|}
\hline & Mean & S.D. & 1 & 2 & 3 & 4 & 5 \\
\hline 1. Marketing innovation & 1.73 & 0.63 & 1 & & & & \\
\hline 2. Organizational innovation & 1.66 & 0.57 & $0.368^{* *}$ & 1 & & & \\
\hline 3. Product innovation & 1.62 & 0.48 & $0.476^{* *}$ & $0.367^{* *}$ & 1 & & \\
\hline 4. Process innovation & 1.61 & 0.57 & $0.388^{* *}$ & $0.266^{*}$ & $0.361^{* *}$ & 1 & \\
\hline 5. Firm performance & 2.11 & 0.67 & $0.489^{* *}$ & 0.172 & $0.397^{* *}$ & $0.378^{* *}$ & 1 \\
\hline
\end{tabular}

Note: Sample size $=59 * \mathrm{p}<0.05, * * \mathrm{p}<0.01$

\section{Stepwise Hierarchical Regression}

Stepwise hierarchical regression tests in Table 5 analyze the role of technological and non-technological innovation on firm performance. In order to examine the effects of non-technological and technological innovation on firm performance, independent variables added to the test separately in Model 1 and Model 2 respectively. Results from the test show that in Model 1 under the strong influence of marketing innovation, the organizational innovation $(\beta=-0.009)$ dimension has no effect on firm performance. Model 2 shows that both dimensions of technological innovation have a positive effect on firm performance. However product and process innovation together represent $22.1 \%$ of total variance, which is less than those of non-technological innovation dimensions (24.0\%). Finally, in Model 3 all dimensions of technological and non-technological innovation included to the stepwise hierarchical regression test to find out the most influential innovation factors on firm performance. Model 3 shows that except organizational innovation, all other innovation types positively affect firm performance. An important finding in this final model is under the pressure of non-technological innovation factors, the impact of process innovation $(\beta=0.194, \mathrm{p}<0.05)$ on firm performance is stronger than that of product innovation $(\beta=0.187, \mathrm{p}<0.05)$.

Table 5. Stepwise Hierarchical Regression Analysis For Hypothesizes

\begin{tabular}{llcc}
\hline & \multicolumn{2}{c}{ Dependent Variable: Firm Performance } \\
& Model 1 & Model 2 & Model 3 \\
\hline Non-Technological Innovation & & & $0.354^{* *}$ \\
Marketing Innovation & $0.493^{* *}$ & -0.078 \\
Organizational Innovation & -0.009 & & $0.187^{*}$ \\
Technological Innovation & & & $0.194^{*}$ \\
Product Innovation & & $0.300^{* *}$ & 0.307 \\
Process Innovation & & $0.270^{*}$ & 5,989 \\
\hline $\mathrm{R}^{2}$ & 0.240 & 0.221 & 7.934 \\
F change & 8,822 & & \\
\hline
\end{tabular}

Note: Sample size $=59 * \mathrm{p}<0.05, * * \mathrm{p}<0.01$

Findings of the stepwise hierarchical regression test support $\mathrm{H} 1 \mathrm{a}, \mathrm{H} 1 \mathrm{~b}$, and $\mathrm{H} 2 \mathrm{~b}$ hypothesis, however, do not support H2a hypothesis. Therefore, the authors conclude that findings of the empirical study fully support $\mathrm{H} 1$ hypothesis and partially support $\mathrm{H} 2$ hypothesis. 


\section{CONCLUSION}

The aim of this study was to investigate the impacts of technological (product and process innovation) and non-technological innovation (organizational and marketing innovation) on firm performance in a firm operating in Turkish telecommunication industry. The field study of the present study was carried out at the first and the largest integrated telecommunications company, TTG Antalya Office, which is one of the most innovative industries in the country, and has achieved an assertive position with its mobile phone subscribers; asymmetric digital subscriber line customers and quality in the field telecommunication industry. The research questions were pursued through questionnaires with top-level managers of the firm. The empirical results from the TTG Antalya Office confirm the hypotheses.

Analysis results demonstrated that both product and process innovation has significant and positive impact on firm performance in TTG Antalya Office. These findings are consistent with Atalay, et al. (2013). Therrien et al. (2011), Gunday et al. (2011) and Artz et al. (2010). It was concluded that the firm in the telecommunication industry, at least in this study, managed product and process innovation in a balanced way for a sustainable competitive advantage. This may be due to the fact that the telecommunication industry is a technological intensive industry based on innovative product and service. Thus, Türk Telekom tends to focus on technological innovations and it requires a particular engagement in process and product innovation in order to improve performance in order to improve performance.

Furthermore, the results provide support for the non-technological innovations, only marketing innovation has significant and positive impact on firm performance in TTG Antalya Office. This may be due to the fact that TTG developed "Turk Telekom Portal" project in 2014 which aims to develop effective marketing strategies; offer the most innovative solutions to customers and acquire knowledge from market. On the other hand, the insignificance of organizational innovation on this relationship can be explained by the fact that Antalya was chosen as the first pilot region within the scope of this project in Turkey. Thus, TTG Antalya Office has innovative work designs that are expected to have less need for reorganization.

Consequently, this study contributes to the literature by providing an opportunity to discuss the importance of technological innovations as well as non-technological innovation, at least in this study for effective firm performance in a company operating in Turkish telecommunication industry. The arguments on this subject are still under review because of only a few studies tried to find the impacts of technological and non-technological innovations on firm performance in the telecommunication industry. These findings are encouraging for bringing greater insight into how organizations should enhance their performance with well-managed innovation strategies.

The sample of the study was too small to carry out the tests of the hypotheses proposed for this study. This represents the main limitation of this study, which will be compensated as the field study is completed in other regions of Turkey. Another limitation of this study, as mentioned above, Turk Telekom Portal project examined in this research has been in use for a short period, and therefore this may result in unclear perceptions of the portal in the relationship between technological and non-technological innovations and firm performance from the respondents' perspective. A longitudinal sample collected over multiple points of time would help to support this research objective.

\section{ACKNOWLEDGEMENTS}

We thank to the managers and employees of Turk Telekom Antalya Regional Branch for their assistance in conducting the study and for participating in the survey. 


\section{REFERENCE}

Ali-Yrkkö, J., \& Martikainen, O. (2008). The Impact of Technological and Non-Technological Innovations on Firm Growth. Discussion Papers from The Research Institute of the Finnish Economy, 1-17. Retrieved from: http://www.etla.fi/wp-content/uploads/2012/09/dp1165.pdf.

Artz, K. W., Norman, P. M., Hatfield, D. E., \& Cardinal, L. B. (2010). A longitudinal study of the impact of R\&D, patents, and product innovation on firm performance. Journal of Product Innovation Management , 27 (5), 725-740. http://dx.doi.org/10.1111/j.1540-5885.2010.00747.

Atalay, M., Anafarta, N., \& Sarvan, F. (2013). The Relationship between Innovation and Firm Performance: An Empirical Evidence from Turkish Automotive Supplier Industry. Procedia - Social and Behavioral Sciences , 75, 226-235. http://dx.doi.org/10.1016/j.sbspro.2013.04.026.

Atuahene-Gima, K. (1996). Market orientation and innovation. Journal of Business Research, 35, 93-103.

Baranano, A. M. (2003). The non-technological side of technological innovation: state-of-the-art and guidelines for further empirical research. International Journal of Entrepreneurship and Innovation Management , 3 (1-2), 107-125. http://dx.doi.org/10.1504/IJEIM.

Bartel, C., \& Garud, R. (2009). The role of narratives in sustaining organizational innovation. Organization Science, 20 (1), 107-117.

Boer, H., \& During, W. E. (2001). Innovation, what innovation? A comparison between product, process and organisational innovation. International Journal of Technology Management , 22, 83107. http://dx.doi.org/10.1504/IJTM.2001.002956.

Calantone, R. J., Cavusgil, S. T., \& Zhao, Y. (2002). Learning orientation, firm innovation capability and firm performance. Industrial Marketing Management, 31 (6), 515-524.

http://dx.doi.org/10.1016/S0019-8501(01)00203-6.

Camison, C., \& Vellar-Lopez, A. (2014). Organizational innovation as an enabler of technological innovation capabilities and firm performance. Journal of Business Research , 67 (1), 2891-2902. http://doi.org/10.1016/j.jbusres.2012.06.004.

Chen, J. S., \& Tsou, H. T. (2007). Information technology adoption for service innovation practices and competitive advantage: The case of financial firms. Information Research, 12 (3), Retrieved from: http://www.informationr.net/ir/12-3/paper314.html.

Cozzarin, B. P., \& Percival, J. C. (2006). Complementarities between organisational strategies and innovation. Economics of Innovation and New Technology , 15 (3), 195-217. http://dx.doi.org/10.1080/10438590500222691.

Damanpour, F. (2013). Footnotes to Research on Management Innovation, mimeo, September.

Darroch, J. (2005). Knowledge management, innovation and firm performance. Journal of Knowledge Management , 9 (3), 101-115. http://dx.doi.org/10.1108/13673270510602809.

Elçi, Ş. (2007). Inovasyon: Kalkınmanın ve Rekabetin Anahtarı. Ankara: Technopolis Group Türkiye.

Griffin, A., \& Hauser, J. R. (1996). Integrating R\&D and Marketing: A Review and Analysis of the Literature. Journal of Product Innovation Management , 13 (3), 191-215. http://dx.doi.org/10.1016/0737-6782(96)00025-2.

Gunday, G., Ulusoy, G., Kilic, K., \& Alpkan, L. (2011). Effects of innovation types on firm performance. International Journal of Production Economics , 133 (2), 662-676. http://dx.doi.org/10.1016/j.ijpe.2011.05.014.

Hair, J. F., Anderson, R. E., Tatham, R. L., \& Black, W. C. (1998). Multivariate Data Analysis. NY: Upper Saddle River, New York: Pearson Education.

Han, J. K., Kim, N., \& Srivastava, R. K. (1998). Market Orientation and Organizational Performance: Is Innovation a Missing Link? Journal of Marketing , 62 (4), 30-45. Retrieved from: 
http://bit.ly/1RrNTDy.

Hipp, C., \& Grupp, H. (2005). Innovation in the Service Sector: The Demand of Service-specific Innovation Measurement Concepts and Typology. Research Policy, 517-535. http://dx.doi.org/10.1016/j.respol.2005.03.002.

Hipp, C., Tether, B., \& Miles, I. (2000). The Incidence and Effects of Innovation in Services: Evidence from Germany. International Journal of Innovation Management , 4 (4), 417-453. http://dx.doi.org/10.1142/S1363919600000226.

Jaskyte, K. (2011). Predictors of administrative and technological innovations in nonprofit organizations. Public Administration Review , 71 (1), 77-86.

Jiao, H., Cui, Y., Yunxia, Z., \& Chen, J. (2014). Building entrepreneurs' innovativeness through knowledge management: the mediating effect of entrepreneurial alertness. Technology Analysis \& Strategic Management , 26 (5), 501-516. http://dx.doi.org/10.1080/.

Jiménez-Jiménez, D., \& Sanz-Valle, R. (2011). Innovation, organizational learning and performance. Journal of Business Research , 64 (4), 408-417. http://dx.doi.org/10.1016/j.jbusres.2010.09.010.

Johannessen, J. A. (2008). Organisational innovation as part of knowledge management. International Journal of Information Management , 28 (5), 403-412. doi:10.1016/j.ijinfomgt.2008.04.007.

Johne, A., \& Davies, R. (2000). Innovation in medium-sized insurance companies: how marketing adds value. International Journal of Bank Marketing , 18 (1), 6-14. http://dx.doi.org/10.1108/02652320010315316.

Knott, A. M. (2001). The Dynamic Value of Hierarchy. Management Science , 47 (3), 430-448. http://dx.doi.org/10.1287/mnsc.47.3.430.9776.

Koc, T., \& Ceylan, C. (2007). Factors impacting the innovative capacity in large-scale companies. Technovation, 27 (3), 105-114. doi:10.1016/j.technovation.2005.10.002.

Lewis-Beck, M. S. (1994). Factor Analysis and Related Techniques. Singapore: Sage Publications.

Li, H., \& Atuagene-Gima, K. (2001). Product Innovation Strategy and the Performance of New Technology Ventures in China. Academy of Management Journal , 44 (6), 1123-1134. http://dx.doi.org/10.2307/3069392.

Lin, C. Y., \& Chen, M. Y. (2007). Does innovation lead to performance? An empirical study of SMEs in Taiwan. Management Research News , 30 (2), 115-132. http://dx.doi.org/10.1108/01409170710722955.

Lin, R. J., Chen, R., \& Shun Chiu, K. K. (2010). Customer Relationship Management and Innovation Capability: An Empirical Study. Industrial Management \& Data Systems , 110 (1), 111133. http://dx.doi.org/10.1108/02635571011008434.

Lin, R. J., Chen, R., \& Shun-Chiu, K. K. (2010). Customer relationship management and innovation capability: an empirical study. Industrial Management and Data Systems , 110 (1), 111-133. http://dx.doi.org/10.1108/02635571011008434.

Lundvall, B. A., \& Nielsen, P. (2007). Knowledge management and innovation performance. International Journal of Manpower , 28 (3/4), 207-223.

Mumford, D. M., \& Licuanan, B. (2004). Leading for innovation: Conclusions, issues and directions. The leadership quarterly, 15 (1), 163-171. doi:10.1016/j.leaqua.2003.12.010.

Naidoo, V. (2010). Firm survival through a crisis: The influence of market orientation, marketing innovation and business strategy. Industrial Marketing Management 39(8): , 39 (8), 1311-1320. http://dx.doi.org/10.1016/j.indmarman.2010.02.005.

Nelson, K., \& McCann, J. E. (2010). Designing for knowledge worker retention \& organization performance. Journal of Management \& Marketing Research , 3 (1), 1-18. Retrieved from: http://bit.ly/27r5ruB. 
OECD, \& Eurostat. (1997). Oslo Manual: Proposed Guidelines for Collecting and Interpreting Technological Innovation Data, 2nd Edition. Paris.

OECD, \& Eurostat. (2005). Oslo Manual-Third Edition: Guidelines for Collecting and Interpreting Innovation Data. Paris.

Olson, C. A., \& Schwab, A. (2000). The performance effects of human resource practices: the case of interclub networks in professional baseball, 1991-1940. Industrial Relations: A Journal of Economy and Society, 39, 553-577. Retrieved from: http://bit.ly/1poKFKy.

Schmidt, T., \& Rammer, C. (2007). Non-technological and Technological Innovations: Strange Bedfellows? Mannheim: Centre for European Economic Research. Retrieved from: ftp://ftp.zew.de/pub/zew-docs/dp/dp07052.pdf.

Standing, C., \& Kiniti, S. (2011). How can organizations use wikis for innovation? Technovation , 31 (7), 287-295. doi:10.1016/j.technovation.2011.02.005.

Subramanian, A., \& Nilakanta, S. (1996). Organizational Innovativeness: Exploring the Relationship Between Organizational Determinants of Innovation, Types of Innovations, and Measures of Organizational Performance. Omega , 24 (6), 631-647.

Therrien, P., Doloreux, D., \& Chamberlin, T. (2011). Innovation novelty and (commercial) performance in the service sector: A Canadian firm- level analysis. Technovation, 31 (12), 655-665. doi:10.1016/j.technovation.2011.07.007.

Tidd, J., Bessant, J., \& Pavitt, K. (. (2001). Managing Innovation: Integrating Technological, Market and Organisational Change, 2nd edition. Chichester: Wiley.

Vakola, M., \& Rezgui, Y. (2000). The role of evaluation in business process re-engineering: two case studies in the construction industry. Knowledge and Process Management , 7 (4), 207-216. http://dx.doi.org/10.1002/1099-1441(200010/12)7:4\%3C207::AID-KPM108.

Venkatraman, N. (1989). Strategic Orientation of Business Enterprises: The Construct, Dimensionality and Measurement. Management Science , 35 (8), 942-962. http://dx.doi.org/10.1287/mnsc.35.8.942.

Wiig, K. M. (1997). Knowledge management: Where did it come from and where it will go? Expert Systems with Applications , 13 (1), 1-14. http://dx.doi.org/10.1016/S0957-4174(97)00018-3.

Yang, J. (2010). The knowledge management strategy and its effect on firm performance: A contingency analysis. International Journal of Production Economics , 125 (2), 215-223. http://dx.doi.org/10.1016/j.ijpe.2010.03.012. 


\section{TRANSFER OF COPYRIGHT:}

In the event of its publication we, as the writers of the article title "Impact of technological and nontechnological innovation on firm performance: empirical study at Turk Telekom Group Antalya office" transfer all of its copyrights to Journal of Global Strategic Management.

Writer(s): Khamroz Abdukhoshimov \& Eren Durmuș-Özdemir

Signature:

Institution: Akdeniz University

Adress: İ̇BF, Pınarbaşı Mah. Dumlupınar Blv, Antalya, Turkey 